\title{
Characterization and Analysis of Oil Palm Empty Fruit Bunch (OPEFB) Waste of PT Kharisma Alam Persada South Borneo
}

\author{
Nur Hidayah* and Ikna Urwatul Wusko \\ Department of Industrial Technology, Faculty of Health, Sari Mulia University, Banjarmasin, Kalimantan Selatan
}

\begin{abstract}
Empty oil palm bunches are the largest solid waste produced from the palm oil industry processing. In processing 1 ton of fresh palm oil bunches, $230 \mathrm{Kg}$ of empty palm oil bunches will be produced. Based on previous research, it is known that oil palm empty fruit bunches waste is proven to have a large amount of organic mass such as cellulose, hemicellulose, lignin. Organic content as mentioned is rich in benefits so that it can be used as raw material for making daily needs products ranging from food to complementary products such as household appliances, clothing and so on. For this reason, a study was conducted on the content of oil palm empty bunches originating from waste at PT. Kharisma Alam Persada. The characterization process was carried out using the SNI method 0128911992. From the research carried out it was found that the cellulose, hemicellulose and lignin content were $55.75 \% ; 28.93 \%$ and $15.32 \%$ respectively. So that it is possible to be used as raw material for processing other products.
\end{abstract}

Keywords: Cellulose; hemicellulose; lignin; oil palm empty bunches

\section{INTRODUCTION}

Palm oil is one of the commodities of plantation products that has an important role in economic activities in Indonesia. Palm oil is also one of Indonesia's important export commodities as a source of foreign exchange besides oil and gas. Indonesia is the world's largest producer and exporter of palm oil. The total area of oil palm plantations in Indonesia before 2017 over the past four years has tended to show an increase, except in 2016 which experienced a decline [Kementrian Pertanian, 2017]. The increase ranged from 2.77 to 4.70 percent per year and decreased in 2016 by 0.52 percent. In 2013 Indonesia's oil palm plantations were recorded at 10.47 million hectares, increasing to 11.26 million hectares in 2015 or an increase of 7.60 percent. In 2016 the area of oil palm plantations decreased by 0.52 percent from 2015 to 11.20 million hectares. Furthermore, in 2017 the area of oil palm plantations is estimated to have increased 9.80 percent from 2016 to 12.30 million hectares [Herawan, T, Rivani, M, 2010]. In contrast to the total area of palm oil, the development of palm oil production (CPO) from 2013 to 2016 has always been increasing annually. From 2013 to 2015, palm oil production increased between 5.67 to 7.70 percent. Then in 2016, palm oil production increased sharply by 53.28 percent from 2015. In 2013 the production of palm oil (CPO) was 17.77 million tons, increasing to 31.49 million tons in 2016 or an increase 77.18 percent. While in 2017

\section{*Corresponding author : Nur Hidayah}

Email : nurhidayah@unism.ac.id it is estimated that palm oil production (CPO) will increase to 34.47 million tons or 9.46 percent [Direktorat Jenderal Perkebunan Indonesia, 2017]. In addition to producing crude palm oil, palm oil mills produce side products in the form of waste. The waste consists of liquid waste from steaming and hydro cyclone discharges, solid waste in the form of OPEFBs, shells and sludge and gas waste from the combustion of OPEFBs or shells [Herawan, T, Rivani, M, 2013]. Based on material mass balance, each palm fresh fruit bunches (FFB) processed in a palm oil mill in addition to producing palm oil will also produce around 25$26 \%$ of oil palm empty fruit bunches [Pusat Penelitian Kelapa Sawit, 2015]. Around 25 million tons of OPEFB were produced by Indonesia in 2013 [Erwinsyah, Atika Afriani, Teddy Kardiansyah, 2015]. Thus, it can be predicted that there will be an increase in solid waste production, one of which is OPEFB. If the "waste" OPEFB is not used and handled properly, it will become a big problem in the future.

Visually, OPEFB is a collection of thick brown fibers that are deliberately set aside after the process of boiling the fruit through a rotary drum thresher in a palm oil processing factory. OPEFB is irregularly shaped and weighs approximately $3.5 \mathrm{~kg}$ and has a thickness of 130 $\mathrm{mm}$ with lengths varying from 170 to $300 \mathrm{~mm}$ and widths from 250 to $350 \mathrm{~mm}$ [Pusat Penelitian Kelapa Sawit, 2015]. Calculation results from 200 samples of OPEFB at the Palm Oil Research Center (PPKS), obtained an average weight of $5.1 \mathrm{~kg}$, a bunch length of $44.8 \mathrm{~cm}$, a width of $35 \mathrm{~cm}$ and a thickness of $19.4 \mathrm{~cm}$. The components of OPEFB 
comprise $57.2 \%$ spikelet, $21.2 \%$ stalk (bunch base), $9.1 \%$ calyx, $5.1 \%$ thorn and $5 \%$ other components [Chang, S.H., 2014]. The types of OPEFB can be distinguished based on the maturity level of fresh fruit bunches (FFB) or better known as the fraction. First, OPEFB with unripe fruit fraction usually looks intact and very compact /dense with a weight of less than $2 \mathrm{~kg}$, the percentage of ripe fruit reaches $40 \%$ and has been released from bunches, spikelet, fruit, calyx still attached very strongly, the stalk is very dense and very difficult to decipher [Wahyono, S., Sahwandan, F. L., Suryanto, F., 2008]. Second, OPEFB with mature fruit fraction has the characteristics of intact and compact, the number of ripe fruit has reached $75 \%$ and has been released from the bunches, spikelet, fruit, calyx still firmly attached to the bunch and the fibers are still difficult to decipher. While the third type of OPEFB with a fraction of fruit through ripe looks fragile, not dense, the percentage of ripe fruit reaches $90 \%$ has been released from the bunch, spikelet is not strong attached to the stalk and fiber is more easily broken down [Aulia Fenny, Marpongahtun, Saharman Gea, 2013].

The chemical composition of the OPEFB fiber consists mainly of lignin, cellulose, and hemicellulose. Cellulose content from OPEFB was $37.50 \%$ [Pusat Penelitian Kelapa Sawit, 2015] lower than cellulose content in wood fiber that was 46.4\% [Bhattacharya, D., Germinario, L. T., Winter, W. T., 2008], bamboo which was $47.5 \%$ [Zhang, Y, Lu, X. B., Gao, C., Lv, W. J., Yao. J. M, 2012], and sugarcane bagasse is 50\% [Binod, P., Sindhu, R., Singhania, R. R., Vikram, S., Devi., L., Nagalaksmi, S., Kurien, N., N. Sukamaran., R. K., Pandey, A., 2010]. The characteristics of OPEFB fibers presented can differ from one source to another depending on age, size, growth phase, geographical location, soil conditions, climatic influences for oil palm growth in the field and testing methods used [Erwinsyah, Atika Afriani, Teddy Kardiansyah, 2015].

Cellulose is the main component that reaches $37 \%$ of very closely associated with hemicellulose and lignin. Cellulose isolation requires intensive chemical treatment. Cellulose consists of D-glucose monomer units bound through $\beta$-1-4-glycosidic. Glucose residues are arranged in 180 o bonds with one another and then the repeating unit of the cellulose chain consisting of two cellulose forms a cellobiose unit. The degree of cellulose polymerization (DP) varies between 7000-15000 glucose units depending on the origin.

Lignin is a tri-dimensional phenylpropanoid polymer that is connected by several different bonds between carbon to carbon and some other bonds between phenyl propane units that are not easily hydrolyzed. Hemicellulose is generally reported to be chemically associated or crossbound with polysaccharides, proteins or lignin, cellulose. Hemicellulose is more soluble than cellulose and can be isolated from wood by extraction. The average degree of polymerization (DP) of hemicellulose varies between 70 and 200 depending on the type of plant. In lignocellulosic material, in general monosaccharides from hemicellulose which is the most xylose. Hemicellulose has different characteristics from cellulose because it has a stronger bond and is relatively easier to hydrolyze into monomers. Hemicellulose dissolves easily in alkalis but is difficult to dissolve in acids. Hemicellulose functions as a supporter of cell walls and acts as a glue between single cells. Hemicellulose has noncrystalline properties and is not fiber, is easy to expand, dissolves in water, is very hydrophilic and is easily soluble in alkali. The high content of hemicellulose contributes to the bond between fibers, because hemicellulose acts as an adhesive in every single fiber [Canham, GR, Overtone, T., 2003].

Based on cellulose, lignin, and hemicellulose chemical components / compounds contained in OPEFB can be converted into high-value products such as biofuel (bioethanol) [Kim et al., 2008], lactic acid [Ven Kates K. V., 1997], bio-composites, cellulose acetate, microcrystalline cellulose, biopolymer or bioplastics and others. In addition, there are many environmentally friendly products that can be made from cellulose such as sugar, polylactic acid (PLA) as a bioplastic material, lignin-based adhesives, activated carbon, vanillin from lignin, food additives and others. The Palm Oil Research Center is currently developing bioplastics and microcrystalline cellulose (MCC) [Chen et al., 2011].

PT. Kharisma Alam Persada is a subsidiary of Amara Group which was acquired in 2012 with an HGU land area: 4,193 $\mathrm{Ha}$ and an area of 3,558.28 palm planted land located in Baringin A Village, Kec. Candi Laras Selatan Regency Tapin, South Kalimantan Province. Amara Group (PT. Agro Maju Raya Group). Established in 2010 with the initial goal of acquiring the plantation sector in Aceh, PT Surya Panen Subur, from PT. Astra Agro Lestari, Tbk. Immediately afterward, Amara was fully supported by strong capital owners to reach 70,000 ha in 2017 and the next target is towards a public company (IPO).

\section{METHODOLOGY}

The methodology used in this study followed the sample testing procedure with SNI number 0128911992 including testing the water content, ash content, protein, fat, crude fiber, 
carbohydrate content [Lestari Ayu Faiza, 2016]. Each treatment at this research was repeated three times.

\section{Water Level}

Dishes that have been cleaned and dried in an oven at $105^{\circ} \mathrm{C}$ for 15 minutes are cooled in a desiccator, then weighed. The sample was weighed as much as 5 grams and put in the cup. The cup that has been filled in the sample is then put into an oven at $105^{\circ} \mathrm{C}$ for 6 hours. The cup is removed from the oven and cooled in a desiccator then weighed. If the weight is still changing, then drying is repeated with the same temperature and time. Drying is carried out 3-4 times or more until a constant weight is obtained as the final weight of the sample. Water content can be calculated based on weight loss, which is the difference between the initial weight of the sample and the final weight of the sample, using the formula:

$$
\text { water level }(\%)=\frac{a-b}{a} \times 100 \%
$$

explanation: a = Initial sample weight (gram); $\mathrm{b}=$ Final sample weight (gram)

\section{Fats level}

Samples from the water content analysis were weighed in filter paper, then installed in a soxhlet flask and condenser. Reflux is done with a fat solvent for 5 hours. After that, the sample is removed from the soxhlet flask, dried and cooled in a desiccator. Then weighed until the weight is constant. Fat content is calculated using the formula:

$$
\text { fats level }(\%)=\frac{a-b}{w} \times 100 \%
$$

explanation: $\mathrm{a}=$ weight of sample + filter paper before extracting (gram); b = weight of sample + filter paper after extracting (gram); $\mathrm{w}=$ sample weight (gram)

\section{Ash level}

The sample is weighed as much as 2-3 grams, then put into a porcelain cup that has a known permanent weight. Samples were arranged on a heater and then blended in an electric furnace at $550^{\circ} \mathrm{C}$ for $5-6$ hours until complete graying. The cup is then cooled in a desiccator, then weighed to a fixed weight. Ash content can be calculated using the formula:

$$
\operatorname{ash} \text { level }(\%)=\frac{w_{1}-w_{2}}{w} \times 100 \%
$$

explanation: $\mathrm{w}=$ sample weight before burned (gram); $w_{1}=$ weight of sample + cup after burned (gram); w2 = weight of empty cup (gram).

\section{Protein}

A sample of 0.1 gram was put into the Kjeldahl flask. The catalyst weighed as much as 1 gram consisting of CuSO4: $\mathrm{Na} 2 \mathrm{SO} 4=1: 1.2$. Subsequently added $2.5 \mathrm{ml}$ of concentrated $\mathrm{H} 2 \mathrm{SO} 4$ and decollated until the liquid is clear green, extraction is continued for 30 minutes. The pumpkin and its contents are cooled to room temperature, then the contents are transferred to a distillation apparatus and $15 \mathrm{ml}$ of $50 \% \mathrm{NaOH}$ is added (until the solution becomes basic). The distillates are stored in a $200 \mathrm{ml}$ Erlenmeyer containing $0.02 \mathrm{~N} \mathrm{HCl}$ until not less than $50 \mathrm{ml}$ distillate, then the results are distilled with $0.02 \mathrm{~N}$ $\mathrm{NaOH}$ accompanied by the addition of a mensel indicator (a mixture of methyl red and methyl blue) 3-4 drops. The treatment is also carried out on blanks.

$$
\text { protein level }(\%)=\frac{a \times N \times 14 \times 6,25}{w} \times 100 \%
$$

explanation: $\mathrm{a}=$ volume difference of $\mathrm{NaOH}$ was used to titrate a sample of blank; $\mathrm{N}=\mathrm{NaOH}$ normality; $\mathrm{W}=$ sample weight (milligram)

\section{The rate of coarse fiber}

A sample of 1 gram was put into a $300 \mathrm{ml}$ Erlenmeyer flask and then added $100 \mathrm{ml} \mathrm{H} 2 \mathrm{SO} 4$ $0.325 \mathrm{~N}$. The material was then hydrolyzed in an autoclave at $105^{\circ} \mathrm{C}$ for 15 minutes. The material is cooled, then added $50 \mathrm{ml}$ of $1.25 \mathrm{~N} \mathrm{NaOH}$ and rehydrolyzed in a $1050 \mathrm{C}$ temperature autoclave for 15 minutes. Material is filtered using filter paper that has been dried and its weight is known. After that the filter paper was washed successively by using hot water, $25 \mathrm{ml} \mathrm{H} 2 \mathrm{SO} 40.325 \mathrm{~N}$, hot water, then $25 \mathrm{ml}$ of acetone or alcohol. The residue and filter paper is dried in an oven at $110^{\circ} \mathrm{C}$ for $1-2$ hours. Crude fiber content can be calculated using the formula:

$$
\text { the rate of coarse fiber }(\%)=\frac{a-b}{w} \times 100 \%
$$

explanation: $\mathrm{a}=$ weight of residue in filter paper that has been dried (gram); b = weight of empty filter paper (gram); w = sample weight (gram).

\section{Carbohydrates}

Carbohydrates by different $=(100 \%-\%$ water level - $\%$ ash level - $\%$ protein - $\%$ fat level $\%$ the rate of coarse fiber). 
Table I. Water level of oil palm empty fruit bunches sample

\begin{tabular}{lccc}
\hline Sample & a (gram) & b (gram) & \% \\
\hline Replicating 1 & 5 & 4.276 & 14.48 \\
Replicating 2 & 5 & 4.2735 & 14.53 \\
Replicating 3 & 5 & 4.271 & 14.58 \\
\hline
\end{tabular}

Table II. Fats level of oil palm empty fruit bunches sample

\begin{tabular}{lcccc}
\hline Sample & a (gram) & b (gram) & w & \% \\
\hline Replicating 1 & 5.1448 & 5.0529 & 4.276 & 2.15 \\
Replicating 2 & 5.1423 & 5.0513 & 4.2735 & 2.11 \\
Replicating 3 & 5.1398 & 5.0497 & 4.271 & 2.13 \\
\hline
\end{tabular}

As for the characteristics of the lignocellulosic biomass content to determine the content of cellulose, lignin, hemicellulose used by the ADS and NDS methods.

\section{Analysis of Neutral Detergent Fiber (NDF)}

A total of 1 gram of sample (a) was put into a $600 \mathrm{ml}$ beaker and $100 \mathrm{ml}$ was added to the NDS solution then heated. The sample is extracted for 60 minutes from starting to boil. The extracted sample was filtered using a previously weighed G3 sand glass plate (b). The residue is rinsed using hot water and acetone. The glass plate and the residue are dried in a $105^{\circ} \mathrm{C}$ oven for \pm 4 hours until the weight is stable. The sample is removed and cooled in a desiccator then the cup is weighed (c).

$$
\% A D F=\frac{c-b}{a} x 100 \%
$$

\section{Analysis of Acid Detergent Fiber (ADF)}

The sample was weighed as much as 1 gram (A) and put into a $600 \mathrm{ml}$ beaker, then $100 \mathrm{ml}$ was added to the ADS solution. The sample is extracted for 60 minutes from starting to boil. The liquid is filtered using a pre-weighed glass plate B (B). The residue is rinsed using hot water and acetone. The residue is dried in a $105^{\circ} \mathrm{C}$ oven for \pm 4 hours until the weight is stable. The cup is removed and cooled in a desiccator. After chilling, the cup is weighed (C). The ADF percentage can be calculated based on the following formula:

$$
\begin{array}{r}
\% A D F=\frac{C-B}{A} \times 100 \% \\
\% \text { hemiselulosa }=\% N D F-\% A D F
\end{array}
$$

\section{Analysis of Cellulose}

Cellulose analysis is a continuation of ADF analysis. The ADF analysis sample that had been weighed (C) plus a $72 \%$ sulfuric acid solution (H2SO4) until submerged for 3 hours. After 3 hours, the residue was rinsed using hot water and acetone. The residue is dried in a $105^{\circ} \mathrm{C}$ oven for \pm 4 hours until the weight is stable, remove and cool in a desiccator. After chilling, the cup is removed from the desiccator and weighed (D).

$$
\% \text { selulosa }=\frac{C-D}{A} x 100 \%
$$

\section{Analysis Lignin}

Lignin analysis is a continuation of ADF and cellulose analysis. The dried sample (D) is then burned in a furnace with a temperature of $\pm 600^{\circ}$ C. The dishes are cooled in a desiccator and weighed (E). The amount of lignin content is calculated using the following equation:

$$
\% \text { lignin }=\frac{D-E}{A} \times 100 \%
$$

\section{RESULT AND DISCUSSION}

Raw materials of oil palm empty fruit bunches used in this study were obtained from PT. Kharisma Alam Persada in Baringin A Village, Kec. Candi Laras Selatan Regency Tapin, South Kalimantan Province. The test results for water level content are given ini the table below.

Based on the results obtained in table I, it can be seen that the oil palm empty fruit bunch waste has average moisture content of $14.53 \%$. The water content in oil palm empty fruit bunches comes from the boiling process with a steam system from the factory which causes the OPEFB to become saturated with water during the boiling process. The value of excess water content can reduce the heating value of the OPEFB fiber. This can hamper the combustion process so that it is not good if used as fuel. Table II shows the fat level analysis of OPEFB.

Basically, OPEFB does not contain oil because oil is only produced in palm fruit. 
Table III. Ash level of oil palm empty fruit bunches sample

\begin{tabular}{lcccc}
\hline Sample & w1 (gram) & w2 (gram) & $\begin{array}{c}\text { w } \\
\text { (gram) }\end{array}$ & \% \\
\hline Replicating 1 & 20.4767 & 20.33 & 4.276 & 2.15 \\
Replicating 2 & 20.4764 & 20.33 & 4.2735 & 2.11 \\
Replicating 3 & 20.4752 & 20.33 & 4.271 & 2.13 \\
\hline
\end{tabular}

Table IV. Protein compound of oil palm empty fruit bunches sample

\begin{tabular}{lccc}
\hline Sample & a (ml) & w (gram) & \% \\
\hline Replicating 1 & 2,5 & 0.1 & 4.375 \\
Replicating 2 & 2,5 & 0.1 & 4.375 \\
Replicating 3 & 2,45 & 0.1 & 4.2875 \\
\hline
\end{tabular}

Table V. The rate of coarse fiber by oil palm empty fruit bunches sample

\begin{tabular}{lcccc}
\hline Sample & a (gram) & b (gram) & $\begin{array}{c}\text { w } \\
\text { (gram) }\end{array}$ & \% \\
\hline Replicating 1 & 1.2342 & 0.8688 & 0.1 & 36.54 \\
Replicating 2 & 1.2361 & 0.8688 & 0.1 & 36.73 \\
Replicating 3 & 1.2356 & 0.8688 & 0.1 & 36.68 \\
\hline
\end{tabular}

Table VI. Carbohydrate compounds of oil palm empty fruit bunches sample

\begin{tabular}{cc}
\hline Sample & \% \\
\hline Replicating 1 & 37.465 \\
Replicating 2 & 37.471 \\
Replicating 3 & 37.474 \\
\hline
\end{tabular}

Table VII. Characterization of oil palm empty fruit bunches sample

\begin{tabular}{cc}
\hline Composition & results (\%) \\
\hline Water level & 14,53 \\
Ash level & 4,87 \\
Protein & 4,35 \\
Fat level & 2,13 \\
The rate of coarse fiber & 36,65 \\
carbohydrate by different & 37,47 \\
\hline
\end{tabular}

But the results of proximate analysis showed a fat content of $2.13 \%$. The oil contained in OPEFB comes from oil palm fruit which is absorbed into the cell wall through the OPEFB fibers by osmosis during the boiling process and the process of shelling of FFB. Besides containing water and fat, OPEFB waste also contains protein and ash content. Respectively $4.35 \%$ and $4.87 \%$. For data on results of the ash level and protein content test results are given in Table III and Table IV.

The largest proximate content is crude fiber and carbohydrates, $36.65 \%$ and $37.47 \%$. Analys result for crude fiber and carbohydrates content are given in table $\mathrm{V}$ and table VI. The large fiber and carbohydrate content causes OPEFB also known as lignocellulosic biomass. lignocellulosic biomass fiber has three main ingredients, namely cellulose, hemicellulose, and lignin. Based on the proximate analysis conducted on the raw materials for the OPEFB waste sample, are given below in table.

Cellulose which has the molecular formula (C6H1005) $\mathrm{n}$ is a long-chain linear glucose polymer that is connected by glycosidic $\beta(1,4)$ bonds. Based on testing conducted by the NDS and ADS solution method it is known that the cellulose content in the OPEFB PT. KAP of $55.75 \%$ as given in table II. In the structure of plant cell walls, cellulose binds to hemicellulose and lignin. In this analysis test, the amount of lignin and hemicellulose were obtained $28.93 \%$ and $15.32 \%$, respectively. Lignin physically encloses microfibril cellulose in a hydrophibric matrix and is covalently bonded to both cellulose and hemicellulose. 
Table VIII. Neutral Detergent Fiber (NDF) analysys of oil palm empty fruit bunches sample

\begin{tabular}{lccc}
\hline Sample & a (gram) & b (gram) & c (gram) \\
\hline Replicating 1 & 1 & 30.25 & 30.8572 \\
Replicating 2 & 1 & 30.25 & 30.8576 \\
Replicating 3 & 1 & 30.25 & 30.8577 \\
\hline
\end{tabular}

Table IX. Acid Detergent Fiber (ADF) analysys of oil palm empty fruit bunches sample

\begin{tabular}{lccc}
\hline Sample & A (gram) & B (gram) & C (gram) \\
\hline Replicating 1 & 1 & 30.25 & 30.7038 \\
Replicating 2 & 1 & 30.25 & 30.7048 \\
Replicating 3 & 1 & 30.25 & 30.7043 \\
\hline
\end{tabular}

Table X. Cellulose analysis of oil palm empty fruit bunches sample

\begin{tabular}{lccc}
\hline Sample & A (gram) & C (gram) & D (gram) \\
\hline Replicating 1 & 1 & 30.7038 & 30.1469 \\
Replicating 2 & 1 & 30.7048 & 30.1475 \\
Replicating 3 & 1 & 30.7043 & 30.146 \\
\hline
\end{tabular}

Table XI. Lignin analysis of oil palm empty fruit bunches sample

\begin{tabular}{lccc}
\hline Sample & A (gram) & D (gram) & E (gram) \\
\hline Replicating 1 & 1 & 30.1469 & 29.858 \\
Replicating 2 & 1 & 30.1475 & 29.858 \\
Replicating 3 & 1 & 30.146 & $29 . .8565$ \\
\hline
\end{tabular}

Table XII. Characterization of fiber's oil palm empty fruit bunches sample

\begin{tabular}{cc}
\hline Composition (\%) & OPEFB \\
\hline Lignin & 28,93 \\
Hemiselulosa & 15,32 \\
Cellulose & 55,75 \\
\hline
\end{tabular}

At present, cellulose is considered as an alternative material that can be used to make environmentally friendly products in various fields of application. Its abundant and renewable availability makes cellulose even more potential to be developed. Based on the results of proximate characteristics tests conducted on palm oil palm empty fruit bunches waste from PT. Kharisma Alam Persada can be seen that this waste is very potential to be used for product applications. The TTKS characteristic values presented may differ from one source to another depending on age, size, growth phase, geographical location, soil conditions, climatic influences for oil palm growth in the field and the testing methods used.

\section{CONCLUSION}

Based on characterization testing using SNI 0128911992 method on palm oil empty fruit bunch waste (OPEFB) PT. Kharisma Alam Persada (KAP) is known that the content of crude fiber and carbohydrates by different are $36.65 \%$ and
$37.47 \%$, respectively. The highest content value compared to other compositions such as water content or fat content, ash content and protein. This shows that OPEFB is. Testing the composition of the fibers in OPEFB produces data on cellulose, lignin and hemicellulose content, respectively at 55.75\%; $28.93 \%$ and $15.32 \%$. The high cellulose content of PT KPA palm oil palm bunches waste has the potential to be used as raw material for hidrogel.

\section{ACKNOWLEDGMENTS}

Thank you to the Ministry of Research, Technology and Higher Education who have provided funding for this research to be carried out and PT. Kharisma Alam Persada for.

\section{REFERENCES}

Aulia Fenny, Marpongahtun, Saharman Gea, 2013, Studi Penyediaan Nanokristal Selulosa Dari Tandan Kosong Sawit (OPEFB), Jurnal Saintia Kimia, 1(2). 
Bhattacharya, D., Germinario, L.T., Winter,W.T., 2008, Isolation, preparation and characterization of cellulose microfibers obtained from bagasse, Carbohydrate Polymers, 73, 371-377.

Binod, P., Sindhu, R., Singhania, R.R., Vikram,S., Devi, L., Nagalakshmi, S., Kurien, N., Sukumaran, R. K., Pandey, A., 2010, Bioethanol production from rice straw: An overview, Bioresource Technology, 101, 4767-4774

Canham GR, Overtone T, 2003, Descryptive Inorganic Chemistry 3rd ed., New York: Freeman and Company.

Chang, S.H., 2014, An Overview of Empty Fruit Bunch from Oil Palm as Feedstock for Biooil Production, Biomass \& Bioenergy, 1-8.

Chen, W., Yu, H., Liu, Y., Hai, Y., Zhang, M., Chen, P., 2011, Isolation and characterization of cellulose nanofibers from four plant cellulose fibers using a chemical-ultrasonic process, Cellulose 18, 433-442.

Direktorat Jenderal Perkebunan Indonesia, 2017, Statistic Perkebunan Indonesia Kelapa Sawit (Oil Palm), Jakarta: Direktorat Jenderal Bina Produksi Perkebunan. Departemen Pertanian, 362.

Erwinsyah, Atika Afriani, Teddy Kardiansyah, 2015, Potensi Dan Peluang Tandan Kosong Sawit Sebagai Bahan Baku Pulp dan Kertas: Studi Kasus Di Indonesia, Jurnal Selulosa 5 (2), 79-88.

Herawan, T., Rivani, M., 2010, Produksi Aseton Butanol-Etanol dari hidrolisat tandan kosong kelapa sawit, Laporan Penelitian Kerjasama PPKS - PTPN IV., 16 pp. Unpublished.

Herawan, T., Rivani, M., 2013, Pemanfaatan Limbah Padat Kelapa Sawit untuk Produksi Green Product, Prosiding Pertemuan Teknis Kelapa Sawit 2013. JCC Jakarta 7-9 Mei 2013, ISBN 978-602-7539-16-7, 181- 190.
Kementerian pertanian, 2017, Outlook komoditi kelapa sawit, Pusat data dan sistem informasi pertanian, 1907-1507.

Kim, T.H., Taylor, F., Hicks, K.B., 2008, Bioethanol production from barley hull using SAA (Soaking in Aqueous Ammonia) pretreatment. Bioresource Technology, 99, 5694-5702.

Lestari, Ayu Faiza, 2016, Pembuatan Hidrogel Nanofiber Selulosa Dari Tandan Kosong Kelapa Sawit (OPEFB), Bogor: Departemen Teknologi Industri Pertanian Institut Pertanian.

Schell, D.J., Riley, C.J., Dowe, N., Farmer, J., Ibsen, K. N., Ruth, M. F., Toon, S.T., Lumpkin, R.E., 2004, A bioethanol process development unit: initial operatingexperiences and results with a corn fiber feedstock, Bioresource Technology, 91, 179-188

Piarpuzán, D. J., A. Quintero, C.A. Cardona, 2011, Empty fruit bunches from oil palm as a potential raw materialfor fuel ethanol production, Biomass and Bioenergy, 35: 1130 - 1137.

Pusat Penelitian Kelapa Sawit, 2015, Luas Area dan Produksi Kelapa Sawit di Indonesi, Bogor: PPKS.

Venkatesh, K.V., 1997, Simultaneous saccharification and fermentation of cellulose to lactic acid, Bioresource Technology, 62, 91-98.

Wahyono, S., Sahwandan, F. L., Dan Suryanto, F., 2008, Tinjauan Terhadap Perkembangan Penelitian Pengolahan Limbah Padat Pabrik Kelapa Sawit, Jurnal Tek. Lingkungan, 6474.

Zhang, Y, Lu, X. B., Gao, C., Lv,W. J., Yao. J. M., 2012, Preparation and Characterization of Nano Crystalline Cellulose from Bamboo Fibers by Controlled Cellulase Hydrolysis, Journal of Fiber Bioengineering \& Informatics, 5, 263271. 